Article

\title{
Solidago virgaurea L. Plant Extract Targeted against Candida albicans to Reduce Oral Microbial Biomass: A Double Blind Randomized Trial on Healthy Adults
}

\author{
Isabelle Prêcheur ${ }^{1,2, *} \mathbb{0}$, Yohan Rolland ${ }^{3}$, Lilia Hasseine ${ }^{4}$, François Orange ${ }^{5}$, Adeline Morisot ${ }^{6}$ \\ and Anne Landreau 4,7,8 \\ 1 Université Nice Côte d'Azur, Faculté de Chirurgie Dentaire, Laboratoire Micoralis EA 7354, \\ 06300 Nice, France \\ 2 Université Nice Côte d'Azur, Centre Hospitalier Universitaire, Pôle Odontologie, 06200 Nice, France \\ 3 Givaudan, Naturex, 84140 Avignon, France; yohan.rolland@givaudan.com \\ 4 Université Nice Côte d'Azur, Centre Hospitalier Universitaire, Laboratoire de Parasitologie-Mycologie, \\ 06200 Nice, France; hasseine.1@chu-nice.fr (L.H.); landreau.a@chu-nice.fr (A.L.) \\ 5 Université Nice Côte d'Azur, Faculté des Sciences, Centre Commun de Microscopie Appliquée (CCMA), \\ 06000 Nice, France; francois.orange@univ-cotedazur.fr \\ 6 Université Nice Côte d'Azur, Centre Hospitalier Universitaire, Département de Santé Publique, \\ 06200 Nice, France; morisot.a@chu-nice.fr \\ 7 Université Nice Côte d'Azur, Institut de Chimie de Nice CNRS UMR 7272, MBVB, 06000 Nice, France \\ 8 Université d'Angers, Faculté de Santé, 49045 Angers, France \\ * Correspondence: isabelle.precheur@univ-cotedazur.fr; Tel.: +33-0489152231
}

Received: 3 February 2020; Accepted: 23 March 2020; Published: 25 March 2020

\begin{abstract}
Oral microbiome plays an important part on oral health and endogenous bacteria and fungi should not be eradicated. However, their proliferation must be controlled by oral hygiene care. In vitro, Solidago virgaurea ssp. virgaurea L. (SV) plant extract inhibits the adherence and hyphal formation of a fungus, Candida albicans. It reduces the biomass of Candida-bacterial biofilms but not fungal or bacterial growth. Unlike chemical antiseptics, like triclosan and chlorhexidine for instance, SV is a plant extract easily biodegradable. The purpose of this study was to assess the in vivo effectiveness of SV extract in reducing oral biomass. A randomized, double-blind clinical study, with dental plaque evaluation designed to assess the effectiveness of a fluorinated toothpaste containing SV (Bucovia ${ }^{\mathrm{TM}}$, Givaudan, Vernier, Switzerland) was conducted. Sixty-six subjects (SV group $n=33$ vs. control $n=33$ ) brushed their teeth twice a day for a 4 -week period. Supragingival dental plaque was sampled. Total bacterial load (broad spectral bacterial quantitative Polymerase Chain Reaction (qPCR)), C. albicans and seven bacterial species were quantified by qPCR. In the Intervention group, there was a decrease of Total bacterial load $(\Delta \mathrm{D} 0 \mathrm{D} 28 p=0.005$ and $\Delta \mathrm{D} 14 \mathrm{D} 28 p=0.026)$, Streptococcus mutans $(\triangle \mathrm{D} 0 \mathrm{D} 14 p=0.024)$ and C. albicans $(\triangle \mathrm{D} 0 \mathrm{D} 28 p=0.022)$. In the Control group Total bacterial load tended to decrease from baseline to day $28(\Delta \mathrm{D} 0 \mathrm{D} 28 p=0.062$ and $\Delta \mathrm{D} 14 \mathrm{D} 28 p=0.009)$. Plaque Index and Gingival Index improved in both groups.
\end{abstract}

Keywords: antiseptics; biodegradable; biofilm; Candida albicans; dental plaque; oral care products; mycobiome; Solidago virgaurea

\section{Introduction}

Recent genomic and proteomic data revealed that more than 800 bacterial and 100 fungal phylotypes could colonize the oral cavity and contribute to oral biofilms. But most of the oral bacterial and fungal species cannot be grown in vitro [1-3]. This might be one reason why the role of fungi in 
oral health and disease has been underestimated [2-4]. Candida albicans is the prominent cultivable fungal species. But the oral mycobiome can harbor other Candida species, such as Candida glabrata, Candida parapsilosis, Candida dublinensis, Candida krusei, or Candida tropicalis. Prominent other oral fungi are Aspergillus, Aureobasidium, Cladosporium, Epicoccum, Fusarium, Malassezia, Mucor, Penicillium, Saccharomyces, Trichophyton, and Wallemia [5,6].

There is a dynamic balance between biofilms and host parameters, such as saliva, healthy diet, and oral hygiene. This balance limits microbial growth, and oral biofilms create a commensal protection against opportunistic pathogens [7-9]. Endogenous bacteria, but also Candida and other fungal species should not be eradicated or unbalanced in oral biofilms [2-4]. But any factor liable to unbalance oral ecosystems can lead to uncontrolled bacterial and fungal growth. As a result, there is a risk of oral infections, mainly dental caries, gingivitis, periodontitis, candidiasis, denture stomatitis, mucositis, delayed repair after oral surgery, and halitosis (bad breath) [10,11]. In healthy individuals carrying C. albicans, this fungus has a yeast form and colonization remains harmless [5]. But it can switch from yeast cells to virulent hyphal cells and cause oral candidiasis. C. albicans and Streptococcus species can co-increase their virulence in invasive candidiasis, but also in dental caries and in peri-implantitis [11,12].

Bacteria and fungi are adherent to oral surfaces and co-aggregating. They form clusters in biofilms, protected by a matrix which contains host and microbial components, including polysaccharides, glycoproteins, proteins, DNA, and lipids. Lipid constituents are poorly investigated. In oral biofilms, host components are derived from saliva, crevicular fluid and gingival epithelial cells. Bacteria and fungi embedded in the biofilm are more resistant to the innate immune system and to antimicrobial therapy [2,13]. In periodontal tissues, innate immunity is a semi-specific first line of defence, which initiates inflammatory reaction in response to oral microbiome dysbiosis [1]. Some microbial constituents trigger innate immunity, and other constituents and toxins are secondly recognized as microbial antigens by adaptative immunity. Innate immunity recruits immune cells to infection site (macrophages, mastocytes, endothelial cells, histiocytes, and fibroblasts) and from bloodstream (neutrophils, basophils, eosinophils, lymphocytes B and T, monocytes, plasmocytes, and platelets) $[13,14]$. During acute phase reaction, hepatocytes synthesize increased quantities of plasma proteins and glycoproteins. These plasmatic immunity mediators form complex activation systems (bradykinin system, fibrin/fibrinolysis system and complement system) $[13,14]$.

A second group of immunity mediators are synthesized by various cell types. Main cell mediators are histamine, serotonin, eicosanoids, free radicals, cytokines, substance $\mathrm{P}$, neurokinin, and enzymes involved in tissue destruction [13-15]. Bunte and Beikler recently reviewed periodontal immunity (2019) [16]. Briefly, the innate immune system activates phagocytosis, the complement system and the adaptative, immune system which is antigen-dependant and mediated by B and T cells. Humoral immunity fights pathogens via antigen-specific antibodies secreted in saliva and crevicular fluid, which neutralize microbial cells and their toxins. Humoral immunity also mediates allergy, autoimmunity, cell memory, and the production of cytokines. Cellular immunity involves macrophages, natural killer cells, apoptosis of bacteria-containing cells mediated by T cells, and secretion of cytokines by endothelial cells and fibroblasts [16]. As a result, microbial pathogenicity is controlled in healthy oral ecosystems.

In periodontitis, the response of the adaptative immune system is altered and the cytokine network is unbalanced, resulting in persistence of inflammation [14,16]. Typical inflammatory reaction is characterized by signs of pain, heat, redness, and swelling. However, destruction of periodontal tissues is most of time painless and (micro)-bleeding is a constant symptom. Periodontologists have paid a special attention to $T$ cells, cytokine unbalance and free radicals [1,13-16]. T cells differentiate in several lineages of T helper (Th) cells. Th1 cells modulate cellular immunity, produce interleukin-2 (IL-2) and interferon gamma (IF- $\gamma$ ), and protect against intracellular bacteria, viruses and protozoa. Th2 cells modulate humoral immunity (activation of B cells and mastocytes), production of IL-4, IL-5, and IL-13, and protect against parasites. Th17 cells produce IL-17 and protect against extracellular 
bacteria and fungi at barrier sites. However, IL-17 could be an important proinflammatory mediator in periodontitis and immune-mediated inflammatory diseases [16]. According to Bunte and Beikler, modulation of the IL-17/IL-23 axis by monoclonal antibodies could have therapeutic applications [16]. Cytokines are proteins secreted by leukocytes and other cells during inflammatory stages. Main cytokines are Tumor Necrosis Factor- $\alpha$ (TNF- $\alpha)$, interleukins, chemokines and interferons. They are intercellular mediators. Periodontal disease is correlated with increased concentrations of serum IL-1, IL-6, prostaglandin and C-reactive proteins (CRP) [15]. Cytokines induce the production of endothelin-1 (ET-1) in endothelial cell, and ET-1 is secreted in serum and saliva. ET-1 constricts smooth muscular cells and stimulates proinflammatory cytokines in periodontal ligament cells [17]. In addition to early diagnosis and follow-up of periodontal lesions, modulation of ET-1 activity is another field of potential therapeutic applications [15]. Finally, phagocytosis of microorganisms by neutrophil leukocytes increases their oxygen consumption and release of oxygenated free radicals (superoxides, hydrogen peroxide, and hydroxide radical). There is an intensive research of drugs and natural compounds to prevent free radicals' damages in inflamed tissues [18-20].

Most toothpastes and mouthwashes contain antiseptic agents, which are mainly bisbiguanides (chlorhexidine, hexetidine), metal ions (stannous fluoride), phenols (triclosan), and quaternary ammonium compounds (QACs: cetyl pyridinium chloride) [21-25]. In vivo, synthetic antiseptics are efficient in reducing oral biomass, but they can alter protective microbial biofilms and allow xerostomia, stomatitis or oral ulcer development [25]. Besides, some colonizing bacteria in the human microbiote possess resistance genes against QACs (Qua-genes such as QuaC). These resistance genes affect efflux pumps in bacteria and reduce bacterial susceptibility to other antiseptics, including cetrimide, benzalkonium chloride, and chlorhexidine [26,27]. In Staphylococcus aureus and Enterococcus faecalis, plasmid-borne qac genes can induce cross resistance with antibiotics such as fluoroquinolones [10,28]. In addition, the wide use of antiseptics in pharmaceuticals and personal care products generates their dispersal in the environment [29,30]. Either from food and/or topical antiseptic products, they are persistent in wastewater and pollute the environment. A long-term toxicity on aquatic animals and humans, as weak endocrine disruptors, is suspected [31-35].

As an alternative, some plants and plant extracts with antimicrobial, anti-inflammatory, and/or antioxidant properties are used in folk medicine to fight oral infections and especially gingivitis and periodontitis [36]. Plant extracts composition is complex, usually not fully elucidated. These extracts are by definition biodegradable in the environment, and in vitro and in vivo studies clarified some of their properties. Plant extracts with antimicrobial properties stricto sensu have been extensively investigated. Main natural compounds described as antimicrobial compounds are essential oils (complex mix of terpenoids and phenylpropane derivatives (aromatic compounds)) and tannins (phenolic products that can precipitate proteins, such as escin) [37-42]. Some vegetal compounds display anti-inflammatory properties, such as vitamins, mineral elements (iron), proteases (papain and bromelain, a mix of acid proteases), or some flavonoids (close to tannins, such as baicalin) [41,43-46]. Vitamins are essential organic substances that are required in small amounts to catalyze metabolic reactions [19]. Only vitamin C, vitamin D, and vitamin B3 could be useful for prevention and treatment of periodontal disease [18,47]. Vitamin C (ascorbate) is a water-soluble vitamin found in citrus fruits and many vegetables. It is the biologically active form of L-ascorbic acid. It is an antioxidant (a reducing agent) and coenzyme in several metabolic reactions, including hydroxylation of proline and lysine during collagen formation. This action on collagen structure is important to periodontium physiology and integrity. Vitamin C is also involved in inflammatory reaction, at the level of phagocytosis and wound healing [18]. Vitamin D is a liposoluble hormone found in the diet, mainly in fatty fish (cod liver oil), chocolate and whole milk. It is also synthesized in the skin from a derivative of cholesterol or ergosterol, under the action of ultraviolet B (UVB) radiation from the Sun. Vitamin D includes cholecalciferols and ergocalciferols, and regulates calcium in opposition to parathyroid hormone. Vitamin D facilitates the intestinal absorption of calcium and phosphorus, and the fixation of calcium on bones. Deficiencies could be involved in periodontitis [18]. Vitamin B3 or niacin is a water-soluble vitamin of the B complex, 
mainly found in food of animal origin (meat, fish) and in whole cereals. Vitamin B3 is required for the formation of coenzymes Nicotinamide Adenine Dinucleotide (NAD) and Nicotinamide Adenine Dinucleotide Phosphate (NADP) (energy metabolism). Vitamin B3 has vasodilating properties. Park et al. (2017) observed that in young adults, periodontitis was significantly associated with lower intakes of niacin, vitamin C, and iron, especially in women and current non-smokers [47]. Finally, iron is a metallic element, constituent of hemoglobins, cytochromes and iron-binding proteins. Iron is a micronutrient involved in the transport of oxygen and cellular redox reaction. Meat and meat products, as well as fish, are its best food sources. Many plants such as almonds, hazelnuts, oatmeal, spinach, lentils, and dates are also a source of iron, but in smaller quantities [47,48]. As a result, in addition to a balanced diet, multivitamins and antioxidants are currently consumed as dietary supplements $[18,48-50]$.

In this context, a new natural component with original antimicrobial properties has been developed for oral care products (Bucovia ${ }^{\mathrm{TM}}$, Givaudan, Vernier, Switzerland). This plant extract was obtained from Solidago virgaurea ssp. virgaurea L. (SV), Asteraceae [51]. SV aqueous extracts mainly contains triterpene saponins, flavonoids and antocyanidines [52]. In vitro, SV extracts are not inhibitors of fungal or bacterial growth [51,52], but they inhibit $C$. albicans genes specific for adhesin and hyphal formation (Hwp1, Als3, Ece1, Sap6, and Hgc1) [53]. The resulting effects are an inhibition of yeast-hyphal transition and a reduced adherence to other $C$. albicans cells, to bacteria (Streptococcus salivarius) and to oral epithelial cells in culture (TR146 cell line). SV extracts also limit biofilm formation and reduce the biomass of pre-grown Candida-bacterial biofilms [53].

The global aim of this work was to avoid both synthetic chemical compounds and broad-spectrum antimicrobial effect in oral care products. The rationale of the present study was to develop a toothpaste with four specifications as follows: (i) It has to reduce oral biomass in order to maintain oral health but (ii) to preserve protective endogenous bacterial/fungal biofilms; (iii) to be harmless for man (no toxicity, absence of molecules suspected of weak endocrine disruptor properties) and (iv) to be harmless for the environment (do not destroy nor impoverish natural resources, not toxic for the environment and easily biodegradable). Specifications (iii) (chemical analysis) and (iv) were established in vitro. The null hypothesis was the assumption that any difference between patients' groups was the result of chance (mainly C. albicans and Total bacterial load, Plaque Index and Gingival Index); that is, that the toothpaste had no effect. A randomized, double-blind clinical study involving 66 healthy adults confirmed that fluorinated toothpaste containing SV extract fulfilled specifications $\mathrm{i}$, ii, and iii (no side-effects).

\section{Results}

\subsection{Participants}

\subsubsection{Flow Diagram}

Alba Science clinical research associate pre-screened 98 subjects assessed for eligibility. Three participants were not fulfilling inclusion criteria, and 14 were included but did not wish to complete the study before the beginning of the study. Fifteen participants failed screening (exclusion criteria) and were withdrawn by Alba Science dental surgeon in charge to collect clinical data and microbial samples. Sixty-six participants completed the study (Figure 1). They brushed their teeth twice a day for a 4-week period.

No adverse events related to the product tested were reported. 


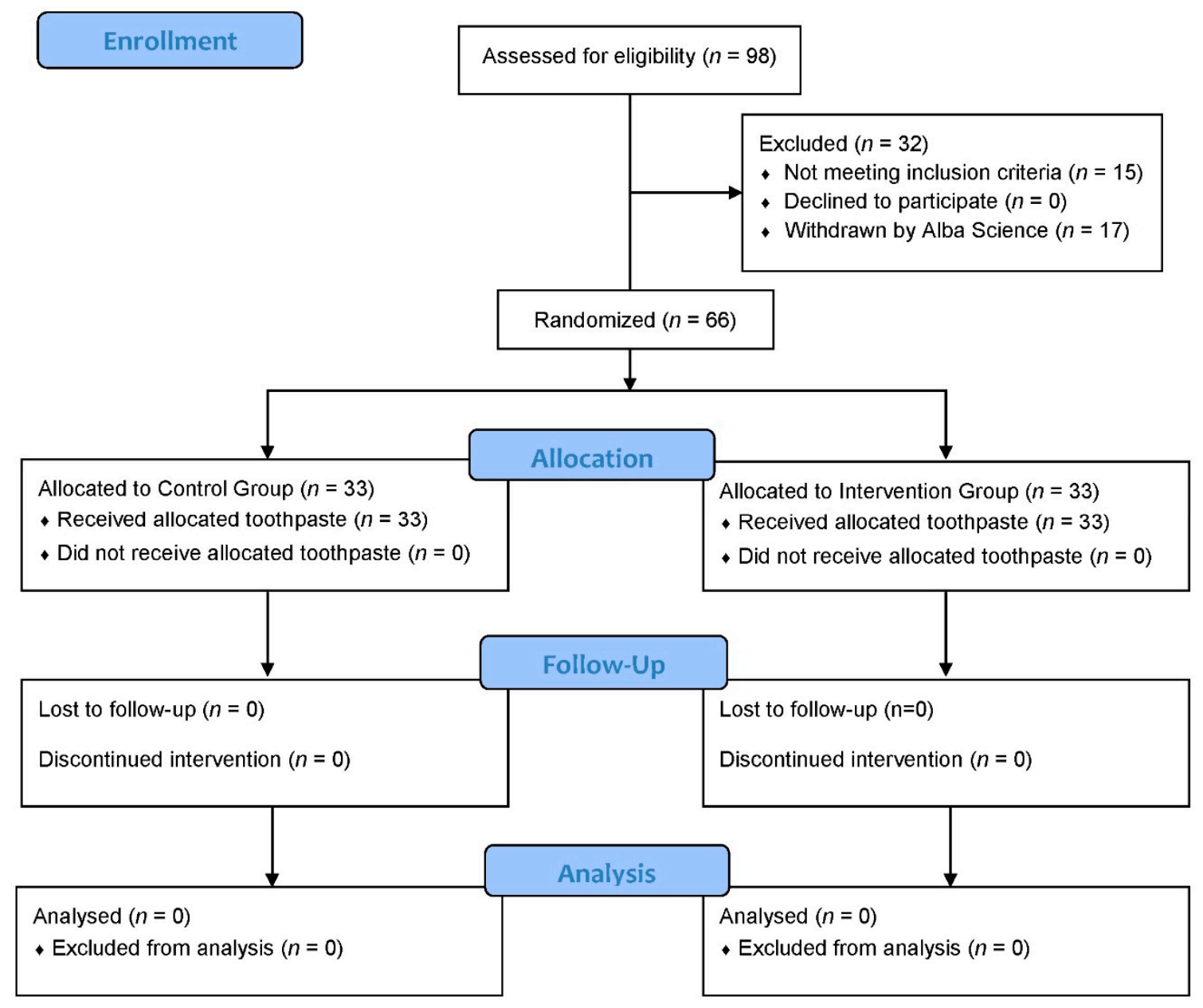

Figure 1. Flow diagram.

\subsubsection{Baseline Characteristics of Participants}

Sixty-six participants completed the study. Baseline characteristics of participants were as follows: 20 males $(30.3 \%)$ and 40 females $(69.7 \%)$; age $41.2(\mathrm{sd}=11)$; Plaque Index $2.34(\mathrm{sd}=0.31)$; Gingival Index $1.57(\mathrm{sd}=0.25)$; Halitosis score $3.33(\mathrm{sd}=0.98)$. Total bacterial load $1.6 \times 10^{9}\left(\mathrm{sd}=6.1 \times 10^{8}\right)$; C. albicans $(\mathrm{n}=13) 5.1 \times 10^{4}\left(\mathrm{sd}=8.7 \times 10^{4}\right)$. Baseline demographic and clinical characteristics were similar $(p>0.05)$ in the Intervention group (33 subjects) vs. Control group (33 subjects) with one exception. There was a higher number of Prevotella intermedia carriers in the Intervention group vs. Control group at baseline $(63.6 \%(21 / 33)$ vs. $24.2 \%(8 / 33) ; p=0.002)$, but values became similar at D14 and D28. Subjects were not carrying all the bacterial and/or fungal species at baseline. The number of subjects carrying a given microbial species at baseline was as follows: Aggregatibacter actinomycetemcomitans 9.1\% (6/66), Fusobacterium nucleatum 57.6\% (38/66), Porphyromonas gingivalis (24.2\% (16/66), P. intermedia $44.0 \%$ (29/66), Treponema denticola 95.5\% (63/66), Tannerella forsythia $62.1 \%(41 / 66)$, Streptococcus mutans $(97.0 \%(64 / 66)$, and C. albicans $20.0 \%(13 / 66)$.

\subsection{Microbial Numeration}

\subsubsection{Quantitative Polymerase Chain Reaction (qPCR) Results}

Species-specific mean values were calculated for the subjects carrying the species at baseline ( $n=$ effective). qPCR numeration results are expressed as mean value (standard error) (Table 1). Paired Student tests (or paired Wilcoxon non parametric tests) were used to compare Intervention group vs. Control group. At baseline, the only difference between Intervention group and Control group was 
the number of subjects carrying $P$ intermedia, which was higher in the Intervention group (21 vs. 8, $p=0.002)$. In the Intervention group, there was a decrease of $S$. mutans load from baseline to D14 $(p=0.024)$ and a decrease of $C$. albicans from baseline to the end of the study $(p=0.022)$ (specification i and ii).

Table 1. Microbial numeration at baseline (D0), D14, and D28.

\begin{tabular}{|c|c|c|c|c|c|}
\hline Microbial Load & D0 & D14 & D28 & $\Delta \mathrm{D} 0 \mathrm{D} 14$ & $\Delta \mathrm{D} 0 \mathrm{D} 28$ \\
\hline$\left(\mathrm{SE}^{1}\right)$ & & & & $p$-Value & $p$-Value \\
\hline \multicolumn{6}{|l|}{ Intervention group $\left(n^{2}\right)$} \\
\hline Total bacterial load & $\begin{array}{c}1.7 \times 10^{9} \\
\left(6.2 \times 10^{8}\right)\end{array}$ & $\begin{array}{c}1.6 \times 10^{9} \\
\left(6.3 \times 10^{8}\right)\end{array}$ & $\begin{array}{c}1.2 \times 10^{9} \\
\left(5.9 \times 10^{8}\right)\end{array}$ & 0.996 & 0.005 \\
\hline A. $a^{3}(4)$ & $\begin{array}{c}9.9 \times 10^{4} \\
\left(8.1 \times 10^{4}\right)\end{array}$ & $\begin{array}{c}1.4 \times 10^{4} \\
\left(1.7 \times 10^{4}\right)\end{array}$ & $\begin{array}{c}5.3 \times 10^{4} \\
\left(8.5 \times 10^{4}\right)\end{array}$ & 0.099 & 0.100 \\
\hline F. nucleatum (21) & $\begin{array}{c}1.5 \times 10^{6} \\
\left(2.6 \times 10^{6}\right)\end{array}$ & $\begin{array}{c}1.5 \times 10^{6} \\
\left(2.3 \times 10^{6}\right)\end{array}$ & $\begin{array}{c}1.0 \times 10^{6} \\
\left(1.7 \times 10^{6}\right)\end{array}$ & 0.509 & 0.370 \\
\hline P. gingivalis (8) & $\begin{array}{c}1.2 \times 10^{7} \\
\left(1.7 \times 10^{7}\right)\end{array}$ & $\begin{array}{c}1.0 \times 10^{7} \\
\left(1.9 \times 10^{7}\right)\end{array}$ & $\begin{array}{c}9.6 \times 10^{6} \\
\left(1.4 \times 10^{7}\right)\end{array}$ & 0.624 & 0.262 \\
\hline P. intermedia (21) & $\begin{array}{c}3.7 \times 10^{6} \\
\left(4.5 \times 10^{6}\right)\end{array}$ & $\begin{array}{c}3.8 \times 10^{6} \\
\left(5.0 \times 10^{6}\right)\end{array}$ & $\begin{array}{c}5.2 \times 10^{6} \\
\left(8.6 \times 10^{6}\right)\end{array}$ & 1 & 0.651 \\
\hline T. denticola (32) & $\begin{array}{c}6.7 \times 10^{5} \\
\left(4.8 \times 10^{6}\right)\end{array}$ & $\begin{array}{c}3.2 \times 10^{6} \\
\left(4.0 \times 10^{6}\right)\end{array}$ & $\begin{array}{c}2.9 \times 10^{6} \\
\left(4.2 \times 10^{6}\right)\end{array}$ & 0.633 & 0.743 \\
\hline T. forsythia (20) & $\begin{array}{c}2.2 \times 10^{6} \\
\left(3.8 \times 10^{6}\right)\end{array}$ & $\begin{array}{c}1.4 \times 10^{6} \\
\left(3.5 \times 10^{6}\right)\end{array}$ & $\begin{array}{c}2.1 \times 10^{6} \\
\left(4.4 \times 10^{6}\right)\end{array}$ & 0.145 & 0.232 \\
\hline S. mutans (32) & $\begin{array}{c}4.3 \times 10^{6} \\
\left(8.0 \times 10^{6}\right)\end{array}$ & $\begin{array}{c}2.6 \times 10^{6} \\
\left(5.9 \times 10^{6}\right)\end{array}$ & $\begin{array}{c}2.9 \times 10^{6} \\
\left(8.8 \times 10^{6}\right)\end{array}$ & 0.024 & 0.090 \\
\hline C. albicans (7) & $\begin{array}{c}6.8 \times 10^{4} \\
\left(1.1 \times 10^{5}\right)\end{array}$ & $\begin{array}{c}8.9 \times 10^{3} \\
\left(1.0 \times 10^{4}\right)\end{array}$ & $\begin{array}{c}1.3 \times 10^{3} \\
\left(2.6 \times 10^{3}\right)\end{array}$ & 0.446 & 0.022 \\
\hline \multicolumn{6}{|l|}{ Control group (n) } \\
\hline Total bacterial load & $\begin{array}{c}1.5 \times 10^{9} \\
\left(6.0 \times 10^{8}\right)\end{array}$ & $\begin{array}{c}1.6 \times 10^{9} \\
\left(5.3 \times 10^{8}\right)\end{array}$ & $\begin{array}{c}1.1 \times 10^{9} \\
\left(6.8 \times 10^{8}\right)\end{array}$ & 0.987 & 0.062 \\
\hline A. $a^{3}(2)$ & $\begin{array}{c}2.2 \times 10^{5} \\
\left(3.0 \times 10^{5}\right)\end{array}$ & $\begin{array}{c}5.6 \times 10^{4} \\
\left(7.5 \times 10^{4}\right)\end{array}$ & $\begin{array}{c}7.5 \times 10^{5} \\
\left(1.0 \times 10^{6}\right)\end{array}$ & - & $\mathrm{NA}^{4}$ \\
\hline F. nucleatum (17) & $\begin{array}{c}2.0 \times 10^{6} \\
\left(4.6 \times 10^{6}\right)\end{array}$ & $\begin{array}{c}2.4 \times 10^{6} \\
\left(4.8 \times 10^{6}\right)\end{array}$ & $\begin{array}{c}2.4 \times 10^{6} \\
\left(4.3 \times 10^{6}\right)\end{array}$ & 0.129 & 0.754 \\
\hline P. gingivalis (8) & $\begin{array}{c}4.8 \times 10^{6} \\
\left(6.5 \times 10^{6}\right)\end{array}$ & $\begin{array}{c}4.7 \times 10^{6} \\
\left(1.1 \times 10^{7}\right)\end{array}$ & $\begin{array}{c}6.8 \times 10^{6} \\
\left(9.3 \times 10^{6}\right)\end{array}$ & 0.944 & 0.362 \\
\hline P. intermedia (8) & $\begin{array}{c}6.8 \times 10^{6} \\
\left(7.1 \times 10^{6}\right)\end{array}$ & $\begin{array}{c}6.9 \times 10^{6} \\
\left(8.6 \times 10^{6}\right)\end{array}$ & $\begin{array}{c}8.6 \times 10^{6} \\
\left(9.5 \times 10^{6}\right)\end{array}$ & 0.293 & 0.441 \\
\hline T. denticola (31) & $\begin{array}{l}2.8 \times 10^{6} \\
\left(3.8 \times 10^{6}\right)\end{array}$ & $\begin{array}{c}2.1 \times 10^{6} \\
\left(2.3 \times 10^{6}\right)\end{array}$ & $\begin{array}{c}2.9 \times 10^{6} \\
\left(4.6 \times 10^{6}\right)\end{array}$ & 0.259 & 0.906 \\
\hline T. forsythia (21) & $\begin{array}{c}1.1 \times 10^{6} \\
\left(1.9 \times 10^{6}\right)\end{array}$ & $\begin{array}{c}8.0 \times 10^{5} \\
\left(1.5 \times 10^{6}\right)\end{array}$ & $\begin{array}{c}1.9 \times 10^{6} \\
\left(3.9 \times 10^{6}\right)\end{array}$ & 0.130 & 0.651 \\
\hline S. mutans (32) & $\begin{array}{c}7.4 \times 10^{6} \\
\left(1.3 \times 10^{7}\right)\end{array}$ & $\begin{array}{c}7.2 \times 10^{7} \\
\left(1.3 \times 10^{7}\right)\end{array}$ & $\begin{array}{c}4.9 \times 10^{6} \\
\left(1.3 \times 10^{7}\right)\end{array}$ & 1 & 0.326 \\
\hline C. albicans (6) & $\begin{array}{c}3.1 \times 10^{4} \\
\left(4.9 \times 10^{4}\right)\end{array}$ & $\begin{array}{c}5.9 \times 10^{4} \\
\left(6.7 \times 10^{4}\right)\end{array}$ & $\begin{array}{c}1.4 \times 10^{4} \\
\left(1.3 \times 10^{6}\right)\end{array}$ & 0.674 & 0.833 \\
\hline
\end{tabular}

${ }^{1}$ SE: standard error; ${ }^{2} n=$ number of subjects carrying a given microbial species; ${ }^{3}$ A. a: Aggregatibacter actinomycetemcomitans; ${ }^{4} \mathrm{NA}$ : not applicable because only two observations.

\subsubsection{Total Bacterial Load}

A linear mixed model was used to compare repeated measure (Total bacterial load) between visits at D0, D14 and D28 and between groups. Mixed analysis showed that Total bacterial load diminished from baseline to the end of the study in the Intervention group ( $\triangle \mathrm{D} 0 \mathrm{D} 28 p=0.005$ and $\Delta \mathrm{D} 14 \mathrm{D} 28$ $p=0.026$ ) (specification $\mathrm{i}$ and ii). There was a tendency to decrease in the Control group from baseline 
to the end of the study $(\Delta \mathrm{D} 0 \mathrm{D} 28 p=0.062)$ and a decrease from D14 to D28 $(\Delta \mathrm{D} 14 \mathrm{D} 28 p=0.009)$ (Table 2).

Table 2. Comparison of Total bacterial load in Intervention group vs. Control group.

\begin{tabular}{ccccc}
\hline Total Bacterial Load & Difference & CI $^{{ }^{1} \text {-Lower }}$ & CI $^{\mathbf{1}}$-Higher & $p$-Value \\
\hline Intergroup comparison & & & & \\
Intervention D0 vs. Control D0 & $-1.7 \times 10^{8}$ & $-6.1 \times 10^{8}$ & $2.7 \times 10^{8}$ & 0.869 \\
Intervention D14 vs. Control D14 & $-1.5 \times 10^{7}$ & $-4.5 \times 10^{8}$ & $4.2 \times 10^{8}$ & 0.999 \\
Intervention D28 vs. Control D28 & $-6.2 \times 10^{7}$ & $-4.9 \times 10^{8}$ & $3.7 \times 10^{8}$ & 0.998 \\
$\quad$ Intragroup comparison & & & & \\
Intervention D0 vs. Intervention D14 & $6.7 \times 10^{7}$ & $-3.3 \times 10^{8}$ & $4.7 \times 10^{8}$ & 0.996 \\
Intervention D0 vs. Intervention D28 & $4.9 \times 10^{8}$ & $9.8 \times 10^{7}$ & $9 \times 10^{8}$ & 0.005 \\
Intervention D14 vs. Intervention D28 & $4.3 \times 10^{8}$ & $3.1 \times 10^{7}$ & $8.3 \times 10^{8}$ & 0.026 \\
Control D0 vs. Control D14 & $-8.9 \times 10^{7}$ & $-4.9 \times 10^{8}$ & $3.1 \times 10^{8}$ & 0.987 \\
Control D0 vs. Control D28 & $3.9 \times 10^{8}$ & $-1.1 \times 10^{7}$ & $7.9 \times 10^{8}$ & 0.062 \\
Control D14 vs. Control D28 & $4.8 \times 10^{8}$ & $7.8 \times 10^{7}$ & $8.8 \times 10^{8}$ & 0.009 \\
\hline
\end{tabular}

${ }^{1} \mathrm{CI}$ : Confidence interval.

\subsection{Participants's Scores and Questionnaire Answers}

Sixty-six patients' oral scores are detailed in Table 3. Briefly, Plaque Index, Gingival Index, and Halitosis score improved similarly, i.e., they diminished in both groups from baseline to the end of the study (paired Student or paired Wilcoxon tests).

Table 3. Comparison of oral clinical parameters from baseline (D0) to the end of the study (D28).

\begin{tabular}{cccc}
\hline Mean Value (SE ${ }^{\mathbf{1}}$ ) & D0 & D28 & p \\
\hline Intervention group $(\boldsymbol{n}=\mathbf{3 3})$ & & & \\
Plaque Index & $2.4(0.4)$ & $2(0.6)$ & $<0.001$ \\
Gingival Index & $1.6(0.3)$ & $1.1(0.6)$ & $<0.001$ \\
Halitosis score & $3.5(0.8)$ & $2(1.2)$ & $<0.001$ \\
Control group $(\boldsymbol{n}=\mathbf{3 3 )}$ & & & \\
Plaque Index & $2.3(0.3)$ & $1.8(0.5)$ & $<0.001$ \\
Gingival Index & $1.5(0.2)$ & $0.9(0.6)$ & $<0.001$ \\
Halitosis score & $3.1(1.1)$ & $1.5(0.9)$ & $<0.001$ \\
\hline
\end{tabular}

${ }^{1}$ SE: Standard error.

Acceptability of the test toothpaste and control toothpaste was good (Table 4). However, there was a trend towards a longer clean feeling in the Intervention group vs Control group (Intervention group $269 \pm 210 \mathrm{~min}$ vs. $193 \pm 233 \mathrm{~min}$ ), with approximately one-hour longer duration but without statistical significance $(p=0.260)$. 
Table 4. Questionnaire responses about the test toothpaste and control toothpaste at the end of the study.

\begin{tabular}{|c|c|c|c|c|c|}
\hline \multicolumn{2}{|r|}{ Questionnaire Responses at D28 } & \multicolumn{2}{|c|}{ Yes } & \multicolumn{2}{|c|}{ No } \\
\hline No. & Question & $\begin{array}{l}\text { Control } \\
\text { group }\end{array}$ & $\begin{array}{l}\text { Intervention } \\
\text { group }\end{array}$ & $\begin{array}{l}\text { Control } \\
\text { group }\end{array}$ & $\begin{array}{l}\text { Intervention } \\
\text { group }\end{array}$ \\
\hline 1 & $\begin{array}{c}\text { The tested product improves } \\
\text { dry mouth? }\end{array}$ & 8 & 7 & 25 & 26 \\
\hline 2 & $\begin{array}{l}\text { The tested product gives clean feeling } \\
\text { in mouth? }\end{array}$ & 23 & 22 & 10 & 11 \\
\hline 3 & $\begin{array}{l}\text { If the tested product gives clean } \\
\text { feeling in mouth, how long? }{ }^{1}\end{array}$ & $\mathrm{NA}^{2}$ & $\mathrm{NA}^{2}$ & $\mathrm{NA}^{2}$ & $\mathrm{NA}^{2}$ \\
\hline 4 & $\begin{array}{l}\text { The tested product delays bad breath } \\
\text { occurring? }\end{array}$ & 20 & 15 & 13 & 18 \\
\hline 5 & $\begin{array}{l}\text { The tested product soothes } \\
\text { irritated gum? }\end{array}$ & 11 & 9 & 22 & 24 \\
\hline 6 & $\begin{array}{l}\text { The tested product reduces gum } \\
\text { redness and swelling? }\end{array}$ & 11 & 12 & 22 & 21 \\
\hline 7 & $\begin{array}{l}\text { The tested product reduces } \\
\text { gum bleeding? }\end{array}$ & 14 & 11 & 19 & 22 \\
\hline 8 & $\begin{array}{l}\text { The tested product reduces biofilm } \\
\text { formation (plaque) on teeth? }\end{array}$ & 20 & 18 & 13 & 15 \\
\hline
\end{tabular}

\section{Discussion}

This work describes a new and natural concept, with a demonstration of efficacy in man: "A SV extract in toothpaste reduced oral microbial biomass. Unlike synthetic antiseptics, this plant extract was able to reduce fungal and bacterial biomass in vivo, despite the fact that it was neither fungicidal nor bactericidal in vitro [51-53]. This result suggests that SV extract could be able to preserve protective oral biofilm [41]. In Table 1, comparison of species-specific microbial load from baseline (D0) to D14 and from baseline to D28 confirmed a synergy between S. mutans and C. albicans previously described by Falsetta et al. in 2014 [12]. The decrease in S. mutans biomass at D14 preceded the decrease in C. albicans biomass at D28. The chemical content of SV extract had been analyzed in a previous work and it did not contain molecules with known endocrine disruptor properties [53]. There was no antiseptic molecules stricto sensu in the formulation of the test toothpaste. In the present clinical study, no side-effects related to the test toothpaste were reported. This extract was obtained from a wild plant S. virgaurea L., which is not a rare or endangered species and it is easily biodegradable in the environment. These results fulfil the specifications (i) to (iv) which had triggered this work.

However, the first limitation of this work is that Carpegen Company did not transmit individual primer sequences and PCR conditions. Abusleme et al. (2013) previously determined Total bacterial load via real-time PCR using universal primers [54]. qPCR detection and quantification of periodontopathogenic bacteria, S. mutans and C. albicans have also been described by other authors, both in experimental in vitro biofilms and in vivo clinical samples [55-59]. However, in these conditions, the present work cannot be repeated by other authors independently of Carpegen Company. Besides, we did not used the $\Delta \Delta \mathrm{Ct}$ method, because Carpegen did not transmit other data than the data listed in the Tables. Therefore, we were not able to calculate the relative fold gene expression of samples in qPCR assays.

Statistically significant reductions by the intervention were observed in Total bacterial load and C. albicans load. But interpretation of the bacterial load result is difficult to interpret, since the initial load in the control group was lower than the intervention group. Important individual variations were observed, as previously reviewed by several authors $[1,2,4]$. But in this work, microbial cell-numbers (genome equivalents) were very high in many cases. The lack of information about qPCR conditions 
limits interpretation of these quantitative results, but sampling protocol could be a significant parameter. In this study, rather large amounts of dental plaque were collected. According to inclusion criteria, subjects participating in the study had an average whole mouth dental plaque scores of $>1.5$ (Plaque Index) and an average gingival score of $>1.0$ (Gingival Index). The sampling method consisted in whole lower jaw scraping of supragingival dental plaque, similarly to Adams et al. sampling method. Usually, sulcus fluid samples for qPCR analyses are taken with paper points [60].

An exclusion criterion for the patients was "untreated caries or significant periodontal disease". But qPCR data for the marker bacteria of caries (S. mutans) and periodontitis (Red complex species: P. gingivalis, T. forsythia, and T. denticola) were all very high (in the order of $10^{6}$ ) and thus suggestive of active diseases. The present results could be explained by sampling method and qPCR protocol. Shifts are observed between health and disease [1,60], and Edlund et al. (2018) observed in vitro that the most abundant taxa were not necessarily the most transcriptionally active taxa [61]. As regards oral streptococci, several authors demonstrated that Streptococcus was the dominant genus in supragingival dental plaque samples collected from healthy children and adults, either caries-free or displaying active caries lesions $[2,3]$. S. mutans was among moderate abundance species in dental plaque of children aged 5-7 [62], but S. mutans and Lactobacillus salivarius were prominent species in the dental plaque of individuals having dental caries [63]. In cavities S. mutans, could account for less than $1 \%$ of the total and active bacterial community [64]. There is a genomic variability of $S$. mutans strains, with large differences in resistance to low $\mathrm{pH}$ and oxidative stress, or in biofilm formation in the presence of sugar. Several authors pointed the risk of generalizing the properties of a given species $[63,64]$. As regards the Red complex species, Peterson et al. (2014) identified T. forsythia but not P. gingivalis or T. denticola in the dental plaque of children 52]. In adults, P. gingivalis and T. denticola share normal microbiota of healthy oral cavity, but poor oral hygiene enhances the count of Veillonella, Prophyromonas, Fusobacterium, and Candida [3]. Red complex species may be underrepresented in the subgingival plaque associated with periodontitis [65], but abundant in mature dental plaque [66].

In the present work, mature biofilm samples were analyzed. Analysis was based on qPCR identification and quantification of C. albicans and seven representative bacterial species. The impact of SV extract on C. albicans morphology and on fungal-bacterial co-aggregation was not investigated in vivo. It would be interesting to analyze by qPCR the expression profile of some clinical samples. For instance, C. albicans possesses important adhesion and hyphal growth associated genes (Hwp1, Als1, Als3, Ece1, and $\mathrm{Hgc1}_{\mathrm{g}}$. S. mutans has specific genes directly associated with extracellular polysaccharide matrix development (Gtfb, Gftc, Gftd, Frua, Dexa, and Gbpb), and with acid stress survival (Atpd and Fabm). P. gingivalis has major fimbrial adhesin (Fima and Arca) [63,67].

A second limitation of this work is that only $20 \%(13 / 66)$ of participants carried C. albicans at baseline. Ghannoum et al. (2010), for instance, identified Candida spp. in $75 \%$ of oral samples of 20 healthy adults, including C. albicans (40\%), Candida tropicalis (15\%), Candida khmerensis (5\%), and Candida metapsilosis (5\%) [5]. Mun et al. (2016), identified Candida spp. in $48 \%$ of 203 healthy adults, and of these Candida strains $85 \%$ were C. albicans. For these authors, Candida carriage was not associated to gender, age or presence of removable dentures, but associated to smoking and the presence of active carious lesions [68]. The low C. albicans carriage observed in the present study could result from exclusion criteria (untreated caries and smoking). Consequently, the scientific hypothesis based on unique inhibition of $C$. albicans adherence properties was not sufficient to explain the decrease in Total bacterial load that was observed with the group of subjects who used Bucovia ${ }^{\mathrm{TM}}$. Actually, saponins interfere with ergosterol, a molecule specific of fungal membranes [69]. Mycobiome analysis demonstrated that many fungal genera can colonize oral cavity, including non-cultivable genera and species $[5,6,70,71]$.

Another explanation of the efficacy of Solidago extract in vivo could result from interactions between lipids, iron, and solidagosaponins, which have detergent and iron chelator properties. Solidago extracts have no hematologic toxicity in man, because saponins, which are present in several vegetables for instance, cannot cross the digestive barrier [72]. The resulting degradation of environmental 
nutriments could hamper microbial growth or adherence. In vitro, Yeast Extract Peptone broth and calf foetal serum are lipid-rich liquid media, which are routinely added to C. albicans cultures in order to promote growth and hyphal formation. In addition, oral anaerobic bacteria require iron or blood-containing culture media to grow. In vivo, gingivitis and periodontitis are microbial and inflammatory gum diseases characterized by occult or macroscopic bleeding. There is also a lipid- and iron-rich exudate called gingival fluid, issued from inflamed sulcus and periodontal pockets. This is why bacterial periodontopathogens, once settled, are auto-maintained [4]. Putative role of SV extract, as a detergent, against the environment of lipophilic oral Malassezia spp. is also addressed [70].

The third limitation of the present study was its duration limited to 4 weeks: Bucovia ${ }^{\mathrm{TM}}$ allowed a better microbial load reduction but Plaque Index or Gingival Index were similar. A mean additional freshness feeling of 76 min was observed, in parallel with the decrease of anaerobic bacteria (Table 1). C. albicans and total bacterial load reduction were observed after a 4-week period of Solidago toothpaste use. This is in line with a 2- to 3-week treatment duration, which is recommended for topical antifungals to treat oral candidiasis (nystatin, amphotericin B, miconazole, sertaconazole). This delay seems necessary to impact Candida in vivo and maybe other endogenous fungi. An additional clinical trial lasting 8 weeks or more, could confirm this hypothesis and improve clinical indices. For instance, recent clinical trials with toothpastes were conducted over periods ranging from 8 to 14 weeks $[60,73,74]$.

This study was limited to 66 subjects and to a 4-week observation period. In the absence of significant Plaque Index and Gingival Index improvement, the results are mostly negative on a clinical point of view. However, the overall ecological effects on the plaque microbiome deserves attention. Indeed, Adams et al. (2017) tested a toothpaste containing enzymes and proteins in a double-blind, randomised, parallel group study involving 93 subjects [60]. The control was a fluorinated toothpaste. The test product (Zendium ${ }^{\mathrm{TM}}$, Unilever, Rotterdam, Nethelands) was the same fluorinated toothpaste containing "three enzyme systems (amyloglucosidase, glucose oxidase and lactoperoxidase), designed to promote the generation of hydrogen peroxide and hypothiocyanite, as well as three further protein components (lysozyme, lactoferrin and immunoglobulin IgG), designed to provide additional antimicrobial benefits". After a 14-week period of use, the authors observed an increase in bacteria associated with gum health and a concomitant decrease in those associated with periodontal disease. C. albicans or other fungi, as well as clinical indexes such as Plaque Index or Gingival Index were not investigated. However, the authors considered that a toothpaste allowing a bacterial shift of the ecology of the oral microbiome was a susceptible to improve oral health [60].

Bucovia $^{\mathrm{TM}}$ was free from tannins, known to induce an unpleasant astringent feeling in the mouth. However, we had difficulties to obtain a discolored extract adapted to oral care product formulations, because most of the filtered extracts and purified solidagosaponins had lost their anti-Candida efficacy. That means that in aqueous extracts, not only saponins but also other components of the plant, are active against biofilms. Indeed, Starks et al. identified some clerodane diterpens from $S$. virgaurea ethanol-ethyl acetate extracts, which had a moderate antibacterial activity and may provide a starting point for the synthesis of more active compounds [75]. Another study found that methanol and water extracts of $S$. virgaurea showed antioxidant activity and try to demonstrate a connection between antioxidant and antimicrobial activity [76]. Due to the chemical complexity of plant extracts, the exact role of major plant components or synergies between plant components still remains in question. However, several clinical studies demonstrated the efficacy of various herbal extracts to reduce plaque deposits and to improve oral conditions such as chronic gingivitis and post-operative dental surgery [39-41,44]. The review of literature revealed that vitamins and antioxidants of vegetal origin could interfere with inflammatory reaction, free radicals and endothelin in damaged periodontal tissues [17-19,48]. They could also interfere with microbial growth and it would be interesting to investigate synergies with $S$. virgaurea extract, eventually as topical adjuncts. In order to confirm the efficiency of this herbal extract, it would be interesting to assay the host inflammatory response on a long-term survey [13]. Saliva and sulcular levels of inflammatory biomarkers associated with chronic periodontitis could be investigated, such as free radicals, cytokines, matrix metalloproteinase (MMP)-2 
and -8 , tissue inhibitor of metalloproteinases (TIMP)-2 complex, or endothelin-1, for instance $[15,17,50]$. A synergy between SV extract and dietary supplements, in particular vitamins with antioxidant properties could be investigated too [20,50].

Laboratory analyses confirmed that Bucovia ${ }^{\mathrm{TM}}$ was easily biodegradable (vegetal origin) and that experimental toothpaste formulated at $0.3 \%$ final concentration was not toxic on mammals. In comparison, some compounds present in essential oils used in toothpastes, such as thymol or carvacrol, are also obtained from plants and they are easily biodegradable too. However, unlike Bucovia $^{\mathrm{TM}}$ they have broad-spectrum bactericidal and fungicidal properties, which have been demonstrated in vitro [37]. Using SV extract we aimed to reduce oral biomass in order to maintain oral health, but we also wanted to avoid a broad-spectrum action, in order to preserve protective endogenous bacterial/fungal biofilms. Vegetal proteases such as papain or bromelain could also help to disintegrate oral biofilm in a non-specific manner $[41,44,46]$.

\section{Materials and Methods}

\subsection{Experimental Toothpastes}

\subsubsection{Plant Material}

Solidago virgaurea ssp. virgaurea L. is a perennial plant common in Europe at low altitude (below $1500 \mathrm{~m}$ ). It grows mainly on fallow lands (not cut meadows). SV is recognizable by its elongated and branched golden yellow flower heads that bloom in summer. It was harvested in its wild state in Poland, by trained harvesters that are able to recognize the species (Naturex for Givaudan, Poland Division). S. virgaurea has been used in European folk medicine for centuries, mostly in traditional use as herbal tea with diuretic properties [72]. S. virgaurea has been thoroughly investigated and it is known to contain flavonoids, triterpenes glycosides and triterpenoids saponins. Plant authentication was achieved with thin layer chromatography (TLC) analysis performed on the raw material to ensure botanical identification and to detect conform vs. non-conform batches [52].

\subsubsection{Solidago virgaurea Extraction Process}

Three kilograms of air-dried S. virgaurea were obtained from $8 \mathrm{~kg}$ of aerial parts of fresh plant. Ground dry herb (500 g) was first extracted with a water/ethanol mixture (70/30) at $50{ }^{\circ} \mathrm{C}$. After separation of the charged liquid and the extracted herb, the liquid was filtered and the ethanol was removed by vacuum distillation. A fractionation step was performed by precipitation of undesirable compounds with addition of ethanol on the concentrate (ratio 1:10). Ethanol was removed by vacuum distillation, and the final concentrate was formulated with vegetal propylene glycol, a suitable solvent to solubilize all active compounds. S. virgaurea extract (Bucovia ${ }^{\mathrm{TM}}$ ) displayed the following physical and chemical characteristics: Liquid, light amber to amber, water soluble, specific gravity $\left(20^{\circ} \mathrm{C}\right)$ : 1.050-1.015, titrated in solidagosaponins and flavonol o-glycosides.

In order to validate SV extract properties before the production of experimental toothpaste, we used oral fungal-bacterial biofilm models in vitro, as previously described [77]. Microscopic examination showed anti-adherence properties of Bucovia ${ }^{\mathrm{TM}} 0.3 \%$, tested in vitro against co-culture of C. albicans and S. salivarius [51,53]. Phase contrast microscopy evidenced dispersion of Candida and Streptococcus cells in culture medium, and short and altered hyphal forms (Figure 2). Scanning electron microscopy evidenced a strong reduction of bacterial cells adherence to Candida cells (Figure 3). 

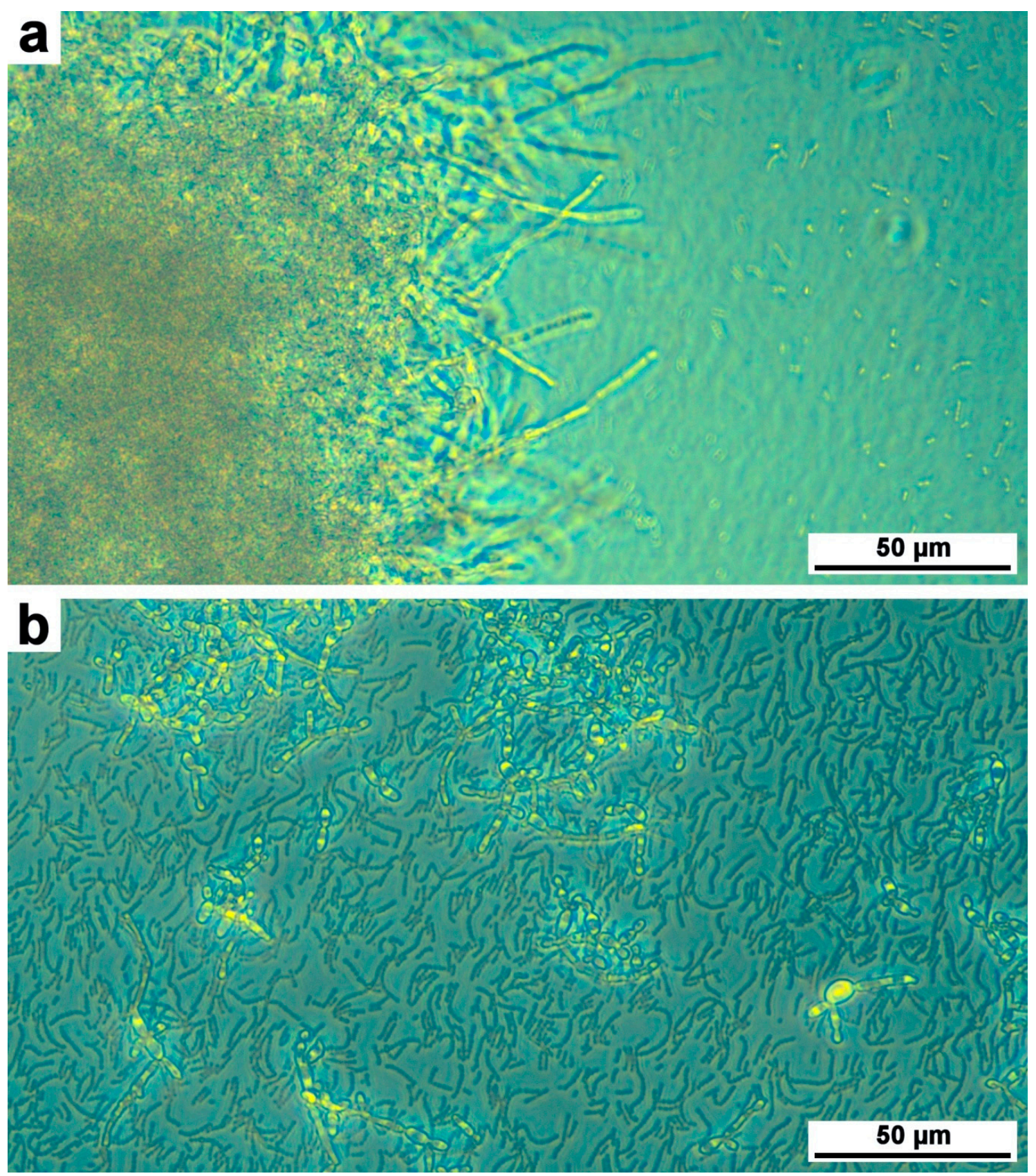

Figure 2. Co-culture of Candida albicans and Streptococcus salivarius. (a) Without Bucovia ${ }^{\mathrm{TM}}$. (b) With Bucovia $^{\mathrm{TM}} 0.3 \%(\times 32)$. 

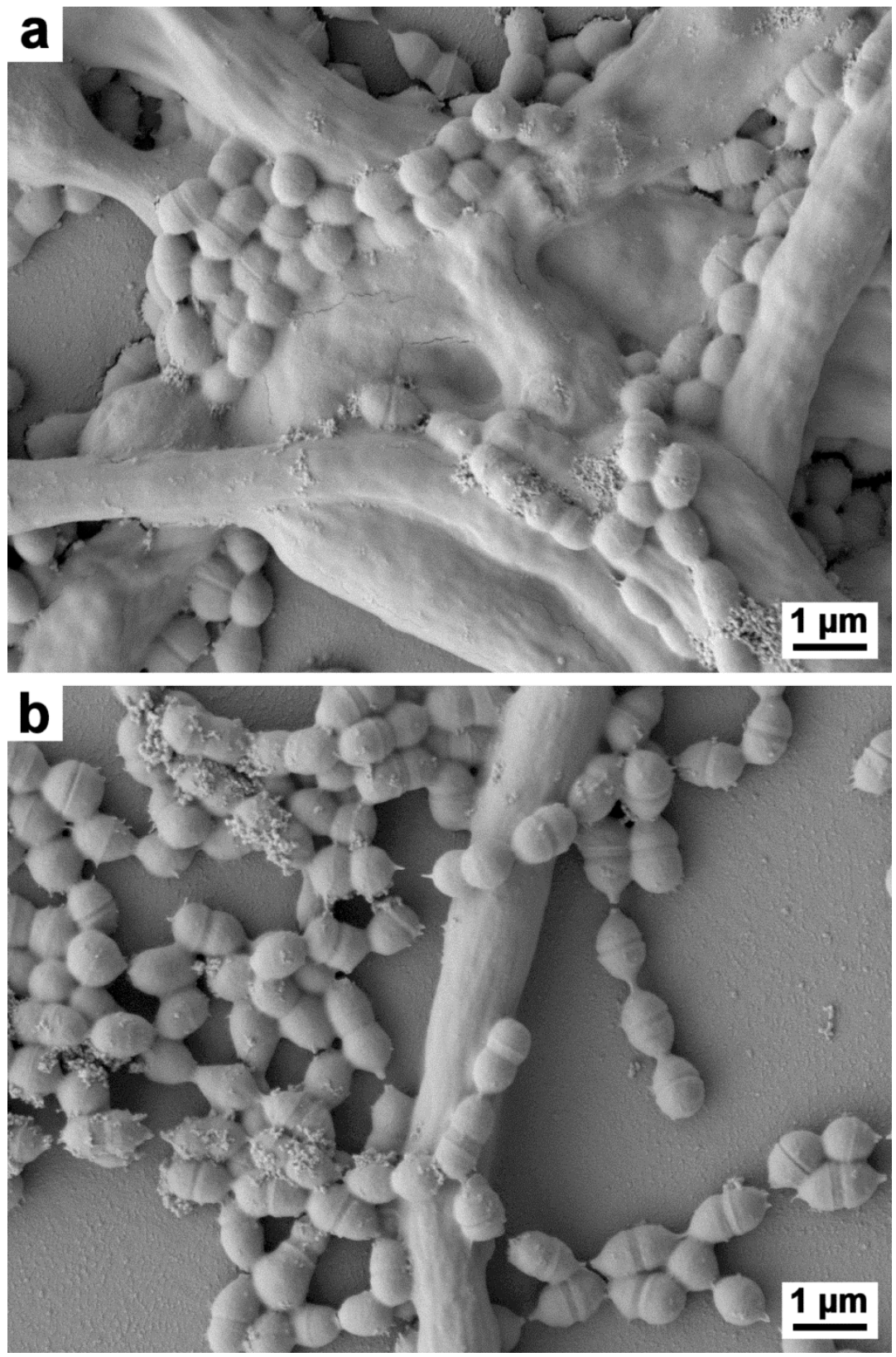

Figure 3. Co-culture of Candida albicans and Streptococcus salivarius. (a) Without Bucovia ${ }^{\mathrm{TM}}$. (b) With Bucovia $^{\mathrm{TM}} 0.3 \%(\times 10,000)$.

\subsubsection{Toothpastes Formulation and Safety Controls}

The product tested was fluorinated toothpaste with Bucovia ${ }^{\mathrm{TM}} 0.3 \%$ final vs. control toothpaste with the active replaced by distilled water. Test and control toothpastes contained sodium fluoride at $0.15 \%$. Excipients were saccharin, sorbitol, glycerine, xanthan gum, carrageenan, hydrated silica, sodium lauryl sulfate, titanium dioxide, and aroma (doublemint flavour); $\mathrm{pH} 6.6 \pm 0.2$. Regulatory safety controls of the experimental toothpaste for the clinical study were carried out by an external independent toxicologist (Evic France laboratory, Vincennes, France). In foreseeable conditions of exposure in cosmetic products, no significant concern was associated to Bucovia ${ }^{\mathrm{TM}}$, which contained SV (aerial parts) extract and natural propylene glycol. Biodegradability fulfilled the standardized Test number 301 of the Organisation for Eonomic Co-operation and Development (OECD 301 B). Bucovia ${ }^{\mathrm{TM}}$ was reported to be easily biodegradable ( $>75 \%$ in 28 days). It was also compliant with all the applicable requirement of the Registration, Evaluation, Authorisation, and Restriction of Chemicals (REACH) 
Regulation of European Commission (EC) N ${ }^{\circ} 1907 / 2006$ and its modifications and updates. These are mandatory and regulatory tests for authorization to use a cosmetic product in a clinical study. European regulations require that these tests be carried out by laboratories approved by the Ministry of Health [78]

\subsection{Clinical Study}

\subsubsection{Hypothesis, Protocol Design, and Ethics Committee}

We hypothesized that fluorinated toothpaste containing Bucovia ${ }^{\mathrm{TM}}$ could reduce oral microbial load by inhibiting C. albicans adherence and the resulting fungal-bacterial development in vivo. We realized a clinical study involving 66 healthy volunteers, Intervention group vs. Control group (33 vs. 33), who used experimental toothpastes twice a day over 28 days. It was a randomized, double-blind evaluation of plaque reduction. The study was achieved by Alba Science (Edinburgh, UK). The protocol was authorized by Reading Independent Ethics Committee (study n ${ }^{\circ} 212415$, Woodley, UK).

\subsubsection{Endpoints}

- $\quad$ Primary endpoint

Primary endpoint was microbial load analysis pre, per and post-treatment, recorded at baseline (D0), after 2 weeks (D14), and after 4 weeks (D28). After $12 \mathrm{~h}$ without oral hygiene, supragingival plaque was harvested by a dental surgeon and pooled. Samples were collected and then stored, shipped within 2 days and kept at $-20^{\circ} \mathrm{C}$ until analysis. C. albicans and seven bacterial species were identified and quantified by qPCR: Aggregatibacter actinomycetemcomitans, Fusobacterium nucleatum, Porphyromonas gingivalis, Prevotella intermedia, Treponema denticola, Tannerella forsythia, and S. mutans. Microbial analyses were achieved by a molecular diagnosis company (Carpegen $\mathrm{GmbH}$, Münster, Germany).

\section{- Secondary endpoints}

Secondary endpoints were oral scores recorded at D0, D7, D14, D21, and D28: Plaque Index, Gingival Index and Halitosis score [79]. Patients' questionnaire responses were recorded at the end of the study (D28): Dry mouth improvement, longer freshness feeling, irritated gum soothing, gum redness and swelling reduction, bleeding of gum or reduction of plaque formation on teeth, and responses on product use. Adverse events were recorded throughout the use period. Restriction during the study was no use of antiseptic mouthwash or other anti-plaque toothpastes containing an active agent such as triclosan.

\subsubsection{Inclusion and Exclusion Criteria}

- Inclusion criteria

Inclusion criteria were as follows: $>18$ in good general health; males and females; having at least 20 natural teeth including 5 teeth (excluding 3rd molars) in each quadrant; average whole mouth dental plaque scores of $>1.5$ by the Turesky modification of the Quigley-Hein index (Plaque Index) and with average score of $>1.0$ by the Loe-Silness Index (Gingival Index) [79].

\section{- Exclusion criteria}

Exclusion criteria were: Untreated caries or significant periodontal disease; full or partial dentures wearers; current orthodontic treatment; oral piercings; smokers or those who have smoked in the preceding five years; and taking dietary supplements (e.g., multivitamins, antioxidants, fish oils). No use of antiseptic mouthwash or toothpaste containing an anti-plaque active agent during the previous month was mandatory. Every subject signed informed consent. 


\subsubsection{Randomization}

Group allocation was randomized by an Alba Science clinical research associate in two blocks with an ALEA function, Excel, and Microsoft Word 2010 suite of programs. Each toothpaste tube was attributed a random number (test and control tubes). An Alba Science dental surgeon investigator enrolled participants and assigned participants to intervention by order of inclusion. Participants were dispensed toothpaste and new standard toothbrush along with diary and instructions of use. The dental surgeon, participants, and later people assessing outcomes were blind to treatment allocation.

\subsubsection{Dental Plaque Sampling}

A single and trained dental-surgeon was in charge of all of the patients participating in the study. Supragingival dental plaque was scraped from the lower teeth, spread onto five paper picks and stored in a labelled Eppendorf tube. Carpegen sent the materials for transportation. No medium was used and Eppendorf tubes were immediately frozen at $-20^{\circ} \mathrm{C}$. Eppendorf tubes were sent from Alba Science (Edinburgh, UK) to Carpegen (Muenster, Germany) in a carboglace, by express mail.

\subsection{6. qPCR Analysis}

Microbial analyses were carried out by Carpegen $\mathrm{GmbH}$. Total bacterial load was measured by a broad spectral "universal" qPCR, according to Carpegen protocol. The samples were analyzed by hydrolysis probe-based real-time PCR assays using the real-time PCR instrument LightCycler $480 \mathrm{II}$ (Roche Molecular Diagnosis, Pleasanton, CA, USA). Singleplex PCR reactions were used, including negative and positive controls for each assay, as well as an internal control reaction to exclude inhibitory effects. Quantification was performed by analyzing serial dilutions of plasmid controls containing the respective cloned target amplicon. Further details of qPCR analysis protocol, including primer and probe sequences, were Carpegen proprietary and could not be disclosed to authors.

\subsubsection{Statistical Method}

Data are reported as mean (standard deviation) or number (\%). Patient's characteristics were compared, Intervention group vs. Control group, using Student's $t$ test or Fisher's exact tests for categorical variables and Chi-square test or Wilcoxon-Mann-Whitney test for continuous variables. Microbial load between baseline, 2-weeks, and 4-weeks and between each groups were compared using paired tests (Wilcoxon-Mann-Whitney or $t$-test) in a linear mixed model. Differences were considered as statistically significant for $p<0.05$. Statistical analyses were performed using $\mathrm{R}$ version 3.5.1. Statistical analyst was blind to intervention.

\section{Conclusions}

In conclusion, inhibition of C. albicans adherence properties, and maybe inhibition of adherence/hyphal formation of other oral fungi, was an original approach for reducing oral biomass because they prevent the development of co-aggregating bacteria. The impact on bacterial microbiota in vitro and in vivo needs further works based on imagery, genomics and proteomics. Additional work could confirm whether this hypothesis could be extended to other hyphae-forming fungal genera in oral and dermatological mycobiome. The clinical trial allowed us to demonstrate that fluorinated toothpaste containing Solidago extract was efficient and safe for reducing oral biomass. Unlike antiseptics, such as triclosan or chlorhexidine, plant extract of $S$. virgaurea is both biodegradable and harmless for host and environment. When they are carefully validated in vitro and in vivo, some plant extracts alone or in combination seem to be a valuable alternative to synthetic antiseptics, at least for daily oral hygiene.

Author Contributions: Conceptualization, I.P. and Y.R.; methodology, I.P. and A.M.; software, A.M.; validation, L.H. and A.L.; formal analysis, A.M.; investigation, I.P. and F.O.; resources, Y.R., F.O.; data curation, Y.R.; writing-original draft preparation, I.P.; writing—review and editing, L.H., F.O., A.M. and A.L.; visualization, 
F.O.; supervision, I.P.; project administration, Y.R.; funding acquisition, Y.R. All authors have read and agreed to the published version of the manuscript.

Funding: This research received no external funding.

Acknowledgments: Authors thank Marlène Chevalier, PhD engineer, for phase contrast microscopy and critical review of the manuscript.

Conflicts of Interest: I.P.: Composition with saponins. Applicant UNIV NICE SOPHIA ANTIPOLIS ETA (FR); CT HOSPITALIER UNIV D (FR); WO2010072923A1. Y.R., L.H., F.O., A.M. and A.L. declare no conflict of interest.

\section{References}

1. Marsh, P.D.; Zaura, E. Dental biofilm: Ecological interactions in health and disease. J. Clin. Periodontol. 2017, 44 (Suppl. 18), S12-S22. [CrossRef]

2. Mira, A. Oral microbiome studies: Potential diagnostic and therapeutic implications. Adv. Dent. Res. 2018, 29, 71-77. [CrossRef] [PubMed]

3. Verma, D.; Garg, P.K.; Dubey, A.K. Insights into the human oral microbiome. Arch. Microbiol. 2018, 200, 525-540. [CrossRef] [PubMed]

4. Wade, W.G. New aspects and new concepts of maintaining "microbiological" health. J. Dent. 2010, 38, S21-S25. [CrossRef]

5. Ghannoum, M.A.; Jurevic, R.J.; Mukherjee, P.K.; Cui, F.; Sikaroodi, M.; Naqvi, A.; Gillevet, P.M. Characterization of the oral fungal microbiome (mycobiome) in healthy individuals. PLoS Pathog. 2010, 6, e1000713. [CrossRef] [PubMed]

6. Limon, J.J.; Skalski, J.H.; Underhill, D.M. Commensal fungi in health and disease. Cell Host Microbe 2017, 22, 156-165. [CrossRef]

7. Lof, M.; Janus, M.M.; Krom, B.P. Metabolic interactions between bacteria and fungi in commensal oral biofilms. J. Fungi 2017, 3, 40. [CrossRef]

8. Bowen, W.H.; Burne, R.A.; Wu, H.; Koo, H. Oral biofilms: Pathogens, matrix, and polymicrobial interactions in microenvironments. Trends Microbiol. 2018, 26, 229-242. [CrossRef]

9. Liu, Y.; Ren, Z.; Hwang, G.; Koo, H. Therapeutic strategies targeting cariogenic biofilm microenvironment. Adv. Dent. Res. 2018, 29, 86-92. [CrossRef]

10. Hong, C.; Aung, M.M.; Kanagasabai, K.; Lim, C.A.; Liang, S.; Tan, K.S. The association between oral health status and respiratory pathogen colonization with pneumonia risk in institutionalized adults. Int. J. Dent. Hyg. 2018, 16, e96-e102. [CrossRef]

11. Koo, H.; Andes, D.R.; Krysan, D.J. Candida-streptococcal interactions in biofilm-associated oral diseases. PLoS Pathog. 2018, 14, e1007342. [CrossRef] [PubMed]

12. Falsetta, M.L.; Klein, M.I.; Colonne, P.M.; Scott-Anne, K.; Gregoire, S.; Pai, C.H.; Gonzalez-Begne, M.; Watson, G.; Krysan, D.J.; Bowen, W.H.; et al. Symbiotic relationship between Streptococcus mutans and Candida albicans synergizes virulence of plaque biofilms in vivo. Infect. Immun. 2014, 82, 1968-1981. [CrossRef] [PubMed]

13. Vestby, L.K.; Gronseth, T.; Simm, R.; Nesse, L.L. Bacterial biofilm and its role in the pathogenesis of disease. Antibiotics 2020, 9, 59. [CrossRef]

14. Blasco-Baque, V.; Garidou, L.; Pomié, C.; Escoula, Q.; Loubières, P.; Le Gall-David, S.; Lemaitre, M.; Nicolas, S.; Klopp, P.; Waget, A.; et al. Periodontitis induced by Porphyromonas gingivalis drives periodontal microbiota dysbiosis and insulin resistance via impaired adaptive immune response. Gut 2017, 66, 872-885. [CrossRef] [PubMed]

15. Bunte, K.; Beikler, T. Th17 cells and the IL-23/IL-17 axis in the pathogenesis of periodontitis and immune-mediated inflammatory diseases. Int. J. Mol. Sci. 2019, 20, 3394. [CrossRef]

16. Moura, M.F.; Navarro, T.P.; Silva, T.A.; Cota, L.O.M.; Soares Dutra Oliveira, A.M.; Costa, F.O. Periodontal and endothelial dysfunction: Periodontal clinical parameters and levels of salivary markers interleukin-1 $\beta$, tumor necrosis factor- $\alpha$, matrix metalloproteinases-2, tissue inhibitor of metalloproteinases- 2 compls, and nitric oxide. J. Periodontol. 2017, 88, 778-787. [CrossRef] [PubMed]

17. Isola, G.; Polizzi, A.; Alibrandi, A.; Indelicato, F.; Ferlito, S. Analysis of Endothelin-1 Concentrations in individuals with periodontitis. Sci. Rep. 2020, 10, 1652. [CrossRef] 
18. Gutierrez Gossweiler, A.; Martinez-Mier, E.A. Chapter 6: Vitamins and oral health. Monogrph. Oral. Sci. 2020, 28, 59-67. [CrossRef]

19. Varela-Lopez, A.; Navarro-Hortal, M.D.; Giampieri, F.; Bullon, P.; Battino, M.; Ouiles, J.L. Nutriceuticals in periodontal health: A systematic review on the role of vitamins in periodontal health maintenance. Molecules 2018, 23, 1226. [CrossRef]

20. Isola, G. Current evidence of natural agents in oral and periodontal health. Nutrients 2020, 12, 585. [CrossRef]

21. Park, J.A.; Lee, J.H.; Lee, H.J.; Jin, B.H.; Bae, K.H. Association of some vitamins and minerals with periodontitis in a nationally representative sample of Korean Young adults. Biol. Trace Elem. Res. 2017, 178, 171-179. [CrossRef] [PubMed]

22. Dommisch, H.; Kuzmanova, D.; Jonsson, D.; Grant, M.; Chapple, I. Effect of micronutrient malnutrition on periodontal disease and periodontal therapy. Periodontology 2000 2018, 87, 129-153. [CrossRef] [PubMed]

23. Gunsolley, J.C. Clinical efficacy of antimicrobial mouthrinses. J. Dent. 2010, 38, S6-S10. [CrossRef]

24. Riley, P.; Lamont, T. Triclosan/copolymer containing toothpastes for oral health (Review). Cochrane Database Syst. Rev. 2013, 12, CD010514. [CrossRef]

25. Tezel, U.; Pavlosthathis, S.G. Quaternary ammonium disinfectants: Microbial adaptation, degradation and ecology. Curr. Opin. Biotechnol. 2015, 33, 296-304. [CrossRef]

26. Zhang, C.; Cui, F.; Zeng, G.M.; Jiang, M.; Yang, Z.Z.; Zhu, M.Y.; Shen, L.Q. Quaternary ammonium compounds (QACs): A review on occurrence, fate and toxicity in the environment. Sci. Total Environ. 2015, 518-519, 352-362. [CrossRef]

27. James, P.; Worthington, H.V.; Parnell, C.; Harding, M.; Lamont, T.; Cheung, A.; Whelton, H.; Riley, P. Chlorhexidine mouthrinse as an adjunctive treatment for gingival health. Cochrane Database Syst. Rev. 2017, 3, CD008676. [CrossRef]

28. Wessels, S.; Ingmer, H. Modes of action of three disinfectant active substances: A review. Regul. Toxicol. Pharm. 2013, 67, 456-467. [CrossRef]

29. Wassenaar, T.M.; Ussery, D.; Nielsen, L.N.; Ingmer, H. Review and phylogenetic analysis of qac genes that reduce susceptibility to quaternary ammonium compounds in Staphylococcus species. Eur. J. Microbiol. Immunol. 2015, 1, 44-61. [CrossRef]

30. Buffet-Bataillon, S.; Tattevin, P.; Maillard, J.Y.; Bonnaure-Mallet, M.; Jolivet-Gougeon, A. Efflux pump induction by quaternary ammonium compounds and fluoroquinolone resistance in bacteria. Future Microbiol. 2016, 11, 81-92. [CrossRef]

31. Von der Ohe, P.C.; Schmitt-Jansen, M.; Slobodnik, J.; Brack, W. Triclosan-The forgotten priory substance? Environ. Sci. Pollut. Res. Int. 2012, 19, 585-591. [CrossRef]

32. Manamsa, K.; Crane, E.; Stuart, M.; Talbot, J.; Lapworth, D.; Hart, A. A national-scale assessment of micro-organic contaminants in groundwater of England and Wales. Sci. Total Environ. 2016, 568, 712-726. [CrossRef]

33. Clarke, B.O.; Smith, S.R. Review of "emerging" organic contaminants in biosolids and assessment of international research priorities for the agricultural use of biosolids. Environ. Int. 2011, 37, 226-247. [CrossRef]

34. Dann, A.B.; Hontela, A. Triclosan: Environmental exposure, toxicity and mechanisms of action. J. Appl. Toxicol. 2011, 31, 285-311. [CrossRef]

35. Bedoux, G.; Roig, B.; Thomas, O.; Dupont, V.; Le Bot, B. Occurrence and toxicity of antimicrobial triclosan and by-products in the environment. Environ. Sci. Pollut. Res. Int. 2012, 19, 1044-1065. [CrossRef]

36. Dinwiddie, M.T.; Terry, P.D.; Chen, J. Recent evidence regarding triclosan and cancer risk. Int. J. Environ. Res. Public Health 2014, 11, 2209-2217. [CrossRef] [PubMed]

37. Witorsch, R.J. Critical analysis of endocrine disruptive activity of triclosan and its relevance to human exposure through the use of personal care products. Crit. Rev. Toxicol. 2014, 44, 535-555. [CrossRef]

38. Salehi, B.; Lopez-Jornet, P.; Pons-Fuster Lopez, E.; Calinia, D.; Sharifi-Rad, M.; Ramirez-Alarcon, K.; Forman, K.; Fernandez, M.; Martorell, M.; Setzer, W.N.; et al. Plant-derived bioactives in oral mucosal lesions: A key emphasis to curcumin, lycopene, chamomile, Aloe vera, green tea and coffee properties. Biomolecules 2019, 9, 106. [CrossRef] [PubMed]

39. Haas, A.N.; Wagner, T.P.; Muniz, F.W.; Fiorini, T.; Cavagni, J.; Celeste, R.K. Essential oils-containing mouthwashes for gingivitis and plaque: Meta-analyses and meta-regression. J. Dent. 2016, 55, 7-15. [CrossRef] 
40. Lombardo Bedran, T.B.; Palomari Spolidorio, D.; Grenier, D. Green tea polyphenol epigallocatechin-3-gallate and cranberry proanthocyanidins act in synergy with cathelicidin (LL-37) to reduce the LPS-induced inflammatory response in a three-dimensional co-culture model of gingival epithelial cells and fibroblasts. Arch. Oral. Biol. 2015, 60, 845-853. [CrossRef] [PubMed]

41. Radafshar, G.; Ghotbizadeh, M.; Saadat, F.; Mirfarhadi, N. Effects of green tea (Camellia sinensis) mouthwash containing $1 \%$ tannin on dental plaque and chronic gingivitis: A double-blind, randomized, controlled trial. J. Investig. Clin. Dent. 2017, 8. [CrossRef] [PubMed]

42. Adami, G.R.; Tangney, C.C.; Tang, J.L.; Zhou, Y.; Ghaffari, S.; Naqib, A.; Sinha, S.; Green, S.J.; Schwartz, J.L. Effects of green tea on miRNA and microbiome of oral epithelium. Sci. Rep. 2018, 8, 5873. [CrossRef] [PubMed]

43. Isola, G.; Matarese, M.; Ramaglia, L.; Iorio-Siciliano, V.; Cordasco, G.; Matarese, G. Efficacy of a drug composed of herbal extracts on postoperative discomfort after surgical removal of impacted mandibular third molar: A randomized, triple blind, controlled clinical trial. Clin. Oral. Investig. 2019, 23, 2443-2453. [CrossRef] [PubMed]

44. Unban, K.; Khatthongngam, N.; Shetty, K.; Khanongnuch, C. Nutritional biotransformation in traditional fermented tea (Miang) from north Thailand and its impact on antioxidant and antimicrobial activities. J. Food Sci. Technol. 2019, 56, 2687-2699. [CrossRef] [PubMed]

45. Choi, K.C.; Son, Y.O.; Hwang, J.M.; Kim, B.T.; Chae, M.; Lee, J.C. Antioxidant, anti-inflammatory and anti-septic potential of phenolic acids and flavonoid fractions isolated form Lilium multiflorum. Pharm. Biol. 2017, 55, 611-619. [CrossRef]

46. Mugita, N.; Nambu, T.; Takahashi, K.; Wang, P.L.; Komasa, Y. Proteases, actinidin, papain and trypsin reduce oral biofilm on the tongue in elderly subjects and in vitro. Arch. Oral Biol. 2017, 82, 233-240. [CrossRef]

47. Seleem, D.; Pardi, V.; Murata, R.M. Review of flavonoids: A diverse group of natural compounds with anti-Candida albicans activity in vitro. Arch. Oral Biol. 2017, 76, 76-83. [CrossRef]

48. De Souza, G.M.; Fernandes, I.A.; Dos Santos, C.R.R.; Falci, S.G.M. Is bromelain effective in controlling the inflammatory parameters of pain, edema, and trismus after lower third molar surgery? A systematic review and meta-analysis. Phytother. Res. 2019, 33, 473-481. [CrossRef]

49. Woelber, J.P.; Bremer, K.; Vach, K.; Konig, D.; Hellwig, E.; Ratka-Kruger, P.; Al-Ahmad, A.; Tennert, C. An oral health optimized diet can reduce gingival and periodontal inflammation in humans-A randomized controlled pilot study. BMC Oral Health 2016, 17, 28. [CrossRef]

50. Isola, G.; Polizzi, A.; Muraglie, S.; Leonardi, R.; Lo Giudice, A. Assessment of vitamin C and antioxidant profiles in saliva and serum in patients with periodontitis and ischemic heart disease. Nutrients 2019, 11, 2956. [CrossRef]

51. Chevalier, M.; Médioni, E.; Prêcheur, I. Inhibition of Candida albicans yeast-hyphal transition and biofilm formation by Solidago virgaurea water extract. J. Med. Microbiol. 2012, 61, 1016-1022. [CrossRef] [PubMed]

52. Laurençon, L.; Sarrazin, E.; Chevalier, M.; Prêcheur, I.; Herbette, G.; Fernandez, X. Inhibition of Candida albicans yeast-hyphal conversion by triterpenoid saponins from the aerial parts of Solidago virgaurea alpestris. Phytochemistry 2013, 86, 103-111. [CrossRef] [PubMed]

53. Chevalier, M.; Doglio, A.; Rajendran, R.; Ramage, G.; Prêcheur, I.; Ranque, S. Acute inhibition of adhesion-specific genes by Solidago virgaurea plant extract causes loss of Candida albicans biofilm integrity. J. Appl. Microbiol. 2019, 23. [CrossRef]

54. Abusleme, L.; Dupuyn, A.K.; Dutzan, N.; Silva, N.; Burleson, J.A.; Strausbaugh, L.D.; Gamonal, J.; Diaz, P.I. The subgingival microbiome in health and periodontitis and its relationship with community biomass and inflammation. ISME J. 2013, 7, 1016-1025. [CrossRef]

55. Stsepetova, J.; Truu, J.; Runne, R.; Nommela, R.; Saag, M.; Olak, J.H.; Nolvak, H.; Preem, J.K.; Oopkaup, K.; Krjutskow, K.; et al. Impact of polyols on oral microbiome of Estonian schoolchildren. BMC Oral Health 2019, 19, 60. [CrossRef]

56. Chen, Z.; Saxena, D.; Caufield, P.W.; Ge, Y.; Wang, M.; Li, Y. Development of species-specific primers for detection of Streptococcus mutans in mixed bacterial samples. FEMS Microbiol. Lett. 2007, 272, $154-162$. [CrossRef] [PubMed]

57. Wu, C.C.; Lin, C.T.; Wu, C.Y.; Peng, W.S.; Lee, M.J.; Tsai, Y.C. Inhibitory effect of Lactobacillus salivarius on Streptococcus mutans biofilm formation. Mol. Oral Microbiol. 2015, 30, 16-26. [CrossRef] [PubMed] 
58. Crisea, G.; Scordino, F.; Romeo, O. Current methods for identifying clinically important cryptic Candida species. J. Microbiol. Methods 2015, 111, 50-56. [CrossRef] [PubMed]

59. Bertolini, M.; Ranjan, A.; Thompson, A.; Diaz, P.I.; Sobue, T.; Maas, K.; Dongari-Bagtzoglou, A. Candida albicans induces mucosal bacterial dysbiosis that promotes invasive infection. PLoS Pathog. 2019, 15, e1007717. [CrossRef]

60. Adams, S.E.; Arnold, D.; Murphy, B.; Carroll, P.; Green, A.K.; Smith, A.M.; Marsh, P.D.; Chen, T.; Marriott, R.E.; Brading, M.G. A randomised clinical study to determine the effect of a toothpaste containing enzymes and proteins on plaque oral microbiome ecology. Sci. Rep. 2017, 7, 43344. [CrossRef]

61. Edlund, A.; Yang, Y.; Yooseph, S.; He, X.; Wenyuan, S.; McLean, J.S. Uncovering complex microbiome activities via metatranscriptomics during 24 hours of oral biofilm assembly and maturation. Microbiome 2018, 6, 217. [CrossRef] [PubMed]

62. Peterson, S.N.; Meissner, T.; Su, A.I.; Snesrud, E.; Ong, A.C.; Schork, N.J.; Bretz, W.A. Functional expression of dental plaque microbiota. Front. Cell. Infect. Microbiol. 2014, 4. [CrossRef] [PubMed]

63. Palmer, S.R.; Miller, J.H.; Abranches, J.; Zeng, L.; Lefebure, T.; Richards, V.P.; Lemos, J.A.; Stanhope, M.J.; Burne, R.A. Phenotypic heterogeneity of genomically-diverse isolates of Streptococcus mutans. PLoS ONE 2013, 8, e61358. [CrossRef]

64. Bedoya-Correa, C.M.; Rincón Rodríguez, R.J.; Parada-Sanchez, M.T. Genomic and phenotypic diversity of Streptococcus mutans. J. Oral Biosci. 2019, 61, 22-31. [CrossRef] [PubMed]

65. Ai, D.; Huang, R.; Wen, J.; Li, C.; Zhu, J.; Xia, L.C. Integrated metagenomics data analysis demonstrates that a loss of diversity in oral microbiota is associated with periodontitis. BMC Genom. 2017, 18, 1041. [CrossRef]

66. Velsko, I.M.; Fellows Yates, J.A.; Aron, F.; Hagan, R.W.; Frantz, L.A.F.; Loe, L.; Martinez, J.B.R.; Chaves, E.; Gosden, C.; Larson, G.; et al. Microbial differences between dental paque and historic dental calculus are related to oral biofilm maturation stage. Microbiome 2019, 7, 102. [CrossRef]

67. Deng, Z.L.; Szafranski, S.P.; Jarek, M.; Bhuju, S.; Wagner-Dobler, I. Dysbiosis in chronic periodontitis: Key microbial players and interactions with the human host. Sci. Rep. 2017, 7, 43344. [CrossRef]

68. Mun, M.; Yap, T.; Alnuaimi, A.D.; Adams, G.G.; McCullough, M.J. Oral candidal carriage in asymptomatic patients. Aust. Dent. J. 2016, 61, 190-195. [CrossRef]

69. Bader, G.; Wray, V.; Hiller, K. The main saponins from the aerial parts and the roots of Solidago virgaurea subsp. virgaurea. Planta Med. 1995, 61, 158-161. [CrossRef]

70. Dupuy, A.K.; David, M.S.; Li, L.; Heider, T.N.; Peterson, J.D.; Montano, E.A.; Dongari-Bagtzoglou, A.; Diaz, P.I.; Strausbaugh, L.D. Redefining the human oral mycobiome with improved practices in amplicon-based taxonomy: Discovery of Malassezia as a prominent commensal. PLoS ONE 2014, 9, e90899. [CrossRef]

71. Chinnici, J.; Yerke, L.; Tsou, C.; Busarajan, S.; Mancuso, R.; Sadhak, N.D.; Kim, J.; Maddi, A. Candida albicans cell wall integrity transcription factors regulate polymicrobial biofilm formation with Streptococcus gordonii. PeerJ 2019, 7, e7870. [CrossRef] [PubMed]

72. Tyszkiewicz, E.W. Assessment Report on Solidago virgaurea L., Herba; Evaluation of medicines for human use; EMEA/HMPC/285759/2007; European Medicines Agency: Amsterdam, The Netherlands, 2008; Available online: http://www.emea.europa.eu (accessed on 2 February 2020).

73. Sälzer, S.; Rosema, N.A.; Martin, E.C.; Slot, D.E.; Timmer, C.J.; Dörfer, C.E.; van der Weijden, G.A. The effectiveness of dentifrices without and with sodium lauryl sulfate on plaque, gingivitis and gingival abrasion-A randomized clinical trial. Clin. Oral Investig. 2016, 20, 443-450. [CrossRef] [PubMed]

74. Athuluru, D.; Reddy, C.; Sudhir, K.M.; Kumar, K.; Gomasani, S.; Nagarakanti, S. Evaluation and comparison of efficacy of three desensitizing dentifrices on dentinal hypersensitivity and salivary biochemical characteristics: A randomized controlled trial. Dent. Res. J. 2017, 14, 150-157.

75. Straks, C.M.; Williams, R.B.; Goering, M.G.; O’Neil-Johnson, M.; Norman, V.L.; Hu, J.F.; garo, E.; Hough, G.W.; Rice, S.M.; Eldridge, G.R. Antibacterial clerodane diterpenes from Goldenrod (Solidago virgaurea). Phytochemistry 2010, 71, 104-109. [CrossRef] [PubMed]

76. Demir, H.; Acik, L.; Burcu Bali, E.; Yasemin Koc, L.; Kaynak, G. Antixoxidant and antimicrobial activities of Solidago virgaurea extracts. Afr. J. Biotechnol. 2009, 8, 274-279.

77. Chevalier, M.; Ranque, S.; Prêcheur, I. Oral fungal-bacterial biofilm models in vitro: A review. Med. Mycol. 2018, 56, 653-667. [CrossRef] [PubMed] 
78. Nobile, V. Guidelines on cosmetic efficacy testing on humans. Ethical, technical, and regulatory requirements in the main cosmetics markets. J. Cosmo. Trichol. 2016, 2, 1. [CrossRef]

79. Rebelo, M.A.B.; Correra de Queiroz, A. Gingival Indices: State of Art, Gingival Diseases-Their Aetiology, Prevention and Treatment; Panagakos, F.S., Davies, R.P., Eds.; InTech: Rijeka, Croatia, 2011; ISBN 978-953-307-376-7. Available online: http://www.intechopen.com/books/gingival-diseases-their-aetiologyprevention-and-treatment/gingival-indices-state-of-art (accessed on 31 October 2019). [CrossRef]

(C) 2020 by the authors. Licensee MDPI, Basel, Switzerland. This article is an open access article distributed under the terms and conditions of the Creative Commons Attribution (CC BY) license (http://creativecommons.org/licenses/by/4.0/). 